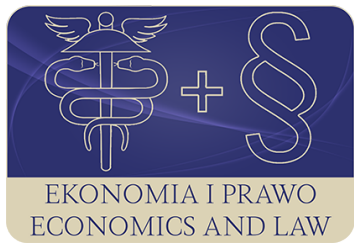

EKONOMIA I PRAWO. ECONOMICS AND LAW

Volume 17, Issue 1, March 2018

p-ISSN 1898-2255, e-ISSN 2392-1625

www.economicsandlaw.pl

EKONOMIA I PRAWO
ECONOMICS AND LAW

ORIGINAL ARTICLE

received 13.06.2017; revised 01.03.2018; accepted 31.03.2018

Citation: Ingram, T., \& Gtód, G. (2018). Organizational resilience of family business: case study.

Ekonomia i Prawo. Ecomomics and Law, 17(1): 57-69. doi:10.12775/EiP.2018.005.

\title{
Organizational resilience of family business: case study
}

\author{
TOMASZ INGRAM \\ corresponding author \\ University of Economics in Katowice, Faculty of Economics, Department of Entrepreneurship \\ and Innovation Management, ul. 1 Maja 50, 40-287 Katowice, Poland \\ $\square$ tomasz.ingram@ue.katowice.pl

\section{GRZEGORZ GEÓD} \\ University of Economics in Katowice, Faculty of Economics, Department of Entrepreneurship \\ and Innovation Management, Poland \\ $\square$ grzegorz.glod@ue.katowice.pl
}

\begin{abstract}
Motivation: Organizational resilience, understood as an ability to survive in harsh market conditions, captures increased research consideration in recent years. The same applies to family businesses that attracted significant attention lately. Although the interest in the topic grows, there are still remaining questions to be answered.

Aim: In the paper we focus on identifying factors affecting organizational abilities to adapt to dynamic, hostile and complex environment especially when disruptive events occur in the environment. Literature studies in the topic allowed development of research proposition - organizational resilience should help to survive negative occurrences in the environment and family business should focus their attention on building resilience capacity while it may allow and facilitate longevity and well-being of an organization.

Results: We illustrate this proposition with the use of two family company cases from the Silesian Voivodeship. The first is a case of a large production company that existed between 2000 and 2013, and after receiving increased growth in 2005-2012 period it went bankrupt in 2014 after two large contracts. The second is a case of a developer company from the same region that started its operation in the same period and managed to develop both its market and products in years. We compare the data flowing from interviews with the owners (that are also managers of these companies) using Eisenhardt methodology and that leads to creation of propositions for future research. Research results indicate
\end{abstract}


there are several factors influencing ability to cope with critical situations. Firstly, we identified that professionalization of management of family business leads to better chances to survive in the environment. Secondly, we conclude that awareness to weak signals diminishes the probability of risky behaviors and helps to survive in dynamic, hostile environment.

Keywords: organizational resilience; family business; case study JEL: M20; H12

\section{Introduction}

Family businesses play important role in the economy. Their significance for societies is widely recognized and attracts increasing research attention in recent years. Despite numerous studies there are still questions to be answered. In particular, still little is known about family business responses to disturbing environmental occurrences. The literature proposes the concept of organizational resilience as the answer to unforeseen critical situations, and numerous scholars contributed to this field of knowledge (Somers, 2009, pp. 12-23). Organizational resilience is usually identified as the ability to survive in the critical situations by adequately responding to environmental challenges. Although the theory was developed after natural disasters and is based on broadly understood systems theory, we believe it is a valuable approach to study survival of family businesses in harsh market conditions (hostile competition, unreliable clients, etc.).

In the paper we focus our attention on identification of factors influencing family business' abilities to adapt to ever changing, dynamic, hostile and unpredictable environment. In particular, we concentrate on finding the answer on the question of how successful family businesses respond to critical situations and what differentiates them from the ones that fail to find adequate answers. To do so we start with brief literature review on the topic of family business features and organizational resilience concept. Secondly, using qualitative research data coming from two companies, one successful and one that failed to survive a critical situation (now nonexistent) we identify characteristics, behaviors and decisions made by the both companies. Their comparison leads to formulation of propositions for future research.

\section{Literature review}

\subsection{Family business - importance for the economy and characteristic features}

Family businesses, understood as a company being owned by a family in at least $50 \%$ and of which owners perceive it as a family business, play an important part of the new national and global economy. Due to their specificity, fam- 
ily businesses faced many difficulties, one of which is to plan and implement the succession strategy (Majda, 2015, pp. 194-209). Family firms play a big role in the commercial life in the emerging markets of Asia and Latin America and have a larger part than is generally acknowledged in developed economies as well. In America, Germany and Italy, such firms create an extremely big cumulative contribution to both labor market and export. It can be noticed that during the last decade, the contest of a strong global economy, new technologies, increasing market opportunities and the participation of a new generation of family members have together encouraged to the increased vitality of family businesses (Carlock \& Ward, 2001).

There is no doubt that the old industrial model government policy makers, economists, and academics has been replaced by the twenty-first-century global economic model. It turned to be helpful in recognizing that entrepreneurial and family enterprises - the oldest form of commercial organizations - are a prime source of wealth creation and employment in both developed and emerging economies. Families control 95\% of the businesses in Asia, the Middle East, Italy, and Spain. In profound industrial economies such as France and Germany, over $80 \%$ of the companies are family supervised. In the United States, with its strong public stock markets, families control $60-70 \%$ of the country's commercial organizations (Kets de Vries et al., 2007). 36\% of companies in Poland have been declared as the family businesses, which are able to produce $18 \%$ of GDP - it results from the report, which was presented in report prepared by Instytut Biznesu Rodzinnego (2016). However, about 92\% of companies are so called 'Potentially family'. They do not admit to their family, because they are afraid of some bad associations resulting from the times of a centrally planned economy in Poland. For comparison, in the United States and Canada, family businesses account for $80 \%$ to $90 \%$ of companies, and in the EU - about $75 \%$.

The contest of a strong global economy, new technologies, increasing market opportunities and the participation of a new generation of family members have together encouraged to the increased vitality of family businesses. Moreover, family businesses are becoming more refined - not only by management but also by more definitely about family business management. For many colleges, universities, trade associations, professional consultants and family business organizations the given family business model is a legitimate subject of their study (Carlock \& Ward, 2001). It could be said that the strategic management process is similar for both nonfamily businesses and family businesses. However, the element of family business makes affect strategy formulation and implementation. There are a few important characteristics of family business that influence strategy, as follows: 'inward' orientation, slower growth and less participation in global markets, long-term commitment, less capital intensive, importance of family harmony, employee care and loyalty, lower costs, generations of leadership, the board's influence on implementation (Harris et al., 1994, pp. 159-176). The research highlights the need for strategic thinking and the role of a shared vision of the future of family and business (Jeżak, 2015). 


\subsection{Organizational resilience - the state of the art and the family business context}

It is not denied that organizations operate in dynamic, highly competitive, and very difficult to foreseen, as well as unstable, environment. This environment is created and shaped by institutions, markets, trends (Lumpkin \& Dess, 2001, pp. 429-451), and sometimes by natural disasters (Boin \& van Eeten, 2013, pp. 429-445). Research attention has been recently directed towards these unpredictable occurrences (for example: terrorist attack of September 11, 2001, Katrina Hurricane, etc.) (see Butts et al. (2012, pp. 1-36); van der Vegt et al. (2015, pp. 971-980)) and currently, scholars and entrepreneurs are searching for managerial solutions that should help organizations in recovering after disruptive events. One of the concepts created recently, that focuses on organizational features and processes allowing quick response to disasters, is organizational resilience, and the research in the topic has grown rapidly in number and quality within last years.

Organizational resilience has its roots in the concept of individual resilience and as such is the anthropomorphisation of individual posture and characteristics (Shin et al., 2012, pp. 727-748); the second basis for studying resilience resides in the field of ecology, as stated by Holling (1973, pp. 1-23). However, there are much more perspectives to be taken into account when researching resilience, for example individual and organizational psychology (Powley, 2009, pp. 1289-1326), strategic management (Hamel \& Valikangas, 2003), safety (Hollnagel et al., 2006) or supply chain management (Sheffi, 2005, pp. 1-11). As Bhamra et al. (2011, pp. 5375-5393), conclude on the basis of literature review covering 74 papers, topics studied in the resilience literature are mostly focused on behaviours and their dynamics, capabilities, strategy and performance and they are related to organizational, individual, socio-ecological (community), purely ecological, and supply chain perspectives.

The basic challenge in respect to organizational resilience is to understand how the processes of guaranteeing organizational efficiency and continuity co-exist with actions related to adaptability that are prerequisite for effective dealing with unanticipated difficulties and challenges associated with unpredicted occurrences. Turner and Kutsch (2016, p. 11836), identify five modes of operations in the critical, crisis situation, and they are: rule-based, resourcing, focus, flexibility, and recovery response archetypes. They are all grounded in the theory of ambidexterity and are related to interplay between exploitative and explorative activities. Such approach emphasizes the need for making organizational decisions linked to the basic dilemma - whether organization tends to exploit opportunities or focus on the process of exploration. The basis for actions in such situations requires adequate first order processes, which are preparation, noticing, interpreting and responding. In the case of model created by Turner and Kutsch (2016, p. 11836), it highlights strong interplay and interrelationships between first order — individual — and second order — 
organizational - activities. As authors emphasize, exploitative and explorative aspects are evident in the crisis, and it is hard to find forthright explanation of why, how and when organization decision-makers focus their attention on either exploration or exploitation. While the study was based on cases (qualitative research), results require confirmation in further, in-depth investigations on organizational behaviors in the face of crisis. However, the study contributes to management theory by showing a valuable lens - organizational ambidexterity - through which organizational resilience may and should be studied.

Kachaner et al. (2012), clearly argue that family businesses, in most cases, are strongly focused on creating resilience capabilities and long-term performance. They direct their attention to controlling expenses by not spending more then they earn, they frequently carry limited debt, acquire fewer and smaller companies, diversify their activity to the higher extent than larger companies, are very ambitious in regard to internationalization, and focus on retaining best employees - talents - more frequently than large organizations. Also, in respect to family business resilience, Danes et al. (2009, pp. 333-349), emphasize, on the basis of National Family Business Panel data, that organizational resilience is strongly related to contribution of employees (human resources), social support, financial capital, exposure to natural disaster and federal assistance given to business-owning families. They conclude, that federal assistance is negatively correlated to firm resilience in case of companies owned by males, while positively in case of female-owned companies. Amann and Jaussaud (2011, pp. 203-223), argue and find empirical evidence that in economic downturns family businesses are more capable of organizing and mobilizing their resource in comparison to non-family business. Their resilience lays in facing down business reality, active searching for meaning of changes and ritualized ingenuity. In sum, on the basis of short review of the literature, it may be argued that family business are better prepared for the unexpected than non-family businesses. However, it still remains a mystery what processes and mechanisms allow them to respond effectively to disruptive events in their environment.

\section{Methods}

To meet the aim of the paper we decided to use qualitative approach focused on identification and understanding of mechanisms by which family business respond to disruptive events. We adopted the approach proposed by Eisenhardt (1989, pp. 532-550) and we combined it with grounded theory approach as suggested by Charmaz (2011, pp. 359-380) and ethnographic approach (Angrosino, 2007). On the basis of literature review an open-ended questions list was prepared, and it contained 18 questions to which respondents were asked to answer. We focused on understanding what actions respondents chose and why they decided to act in a particular way in a crisis situation, allowing respondents to freely speak about their intents, situation they faced, actions and results. Every interview lasted about two hours. All interviews were re- 
corded and further transcribed to word documents - we gathered more than 50 pages of transcripts. In the next step we used simple coding, focused on labeling sentences, parts of a speech. Thus, the study is based on the comparative case study methodology. Further, we concentrated on creating categories from labels. In total more than 350 nodes and 25 categories were created. Next, we focused our attention on linking categories to create a model and the theory behind owners' actions. At this stage we contacted both owners to gather additional information (mainly during informal meetings). Finally, we conducted cross-case analysis to identify similarities and differences between companies and confronted two created models describing behaviors. This allowed us to identify differences between resilient and non-resilient organization and formulate research propositions.

As the concept of resilience is widely studied recently, we used theoretical framework to compare both companies, following Kantur and Say (2015, pp. 456-472) directions as well as Williams et al. recommendations (2016, pp. 1-70), modified with the results of comparative research analysis.

The study of family businesses successes and failures are not widely undertaken in the literature, and data from the GUS - statistical institute of Poland clearly indicate, that more than $40 \%$ of family business are going bankrupt during the first 5 years of operation. The reasons of successes and failures remain unknown. Thus, this study tries to fill in the gap in the current knowledge on the factors behind the success and failure of the medium sized, rapidly growing family businesses. To illustrate it, we purposefully chosen two medium sized, family businesses, both of which were operating in the field of construction, both operating in the same region - Silesian Voivodeship (southern Poland), one of them was closed recently, and the second is growing rapidly. The owners (and CEO's) of the companies are at the same age, mid 40, and have similar experience in business. Both of them started working in a business circa 20 years ago, and have a basic college education in the field of construction and informatics. Both companies started operation at approximately the same time, and hire similar number of employees (the company A - 170 employees in 2014; the company B - 120 employees in 2014, and 150 currently). Evaluating their financial performance, both owners clearly mentioned, that in the time of crises (year 2011 in case of company A, and year 2003 in case of company B) their financial standing was exceptionally good. They made more profit than their main competitors, and they were constantly developing employing more people. Also, the number of projects/clients served was increasing rapidly just before the beginning of the crisis.

The first company, called A in the paper, founded in the 1999, which was producing windows and doors for individual and institutional clients, was closed in 2015, 5 years after significant financial problems arising from signing contracts with fraudulent clients. It was a company well known in the field, and it was awarded 'Business Gazelle' award in 2010 and 2011, as the fastest growing, 
innovative business. After five years of reorganization and downsizing, in 2015, it was closed due to the lack of financial liquidity and numerous debts.

The second company, called B in the paper, founded in the early 1990ies, is currently operating in the field of construction (developer company). Recently founder and CEO decided to expand the scope of activity and opened high standard tennis and fitness club with two restaurants and more than 30 employees (the basic rationale for the business was personal interest in tennis and sport activities).

\section{Results}

In both cases disturbing events were caused by clients, and strictly speaking their destructive behaviors in relation to the business. In relation to the company A, the crisis stroke in the year 2011, as one of its clients did not paid for the ordered products. The amount of the debt equaled to approx. $12 \mathrm{mln}$ PLN, and that was too much for the company to handle. It lost its liquidity and never recovered. This is how the owner A expresses the situation: 'I was believing in clients. Most of my contracts were signed without an in-depth analysis and check. And one of important clients simply did not pay for products and services I made for him. (...) clients in this field of operation may easily avoid or delay payments - for example they do not confirm that the work is done properly, and you cannot issue an invoice. And you have to continue your work for this client, as well as for the others, not to pay fees and charges for not completing the project on time. This is how I felt (...). This company has not paid for the service I made for it. And I had to go to the court. And while it was more than 3 mln EUR contract, I lost my financial liquidity (...)'.

And the second owner says as follows: '(...) there was a time, back in 20032004, when my large clients - mainly mines — stopped paying for services. It was because of their poor financial situation and problems of the sector. This is when I faced largest crisis (...) until now I have no idea how I managed to overcome this situation'. Thus, the situation in both cases was quite similar - clients did not pay for the service they received, and prior investments made by studied companies put them into trouble. In both cases they were large companies buying services from two studied companies that put them in the harsh situation.

However, the crisis faced by the company A has a broader background. As an owner claims, it was all due to the financial crisis in the USA back in 2008/2009. It was a harsh time for construction companies, and as the owner says '(...) everybody was trying to do anything. There were people hired in the company, so we 'get' every opportunity there was on the market. There was no time to check the client. I had to act in a hurry (...)'. It was financial 'bubble' in the USA that caused problems for companies from that field. Banks were reluctant to fund future investments, there were limited investments in progress and firms had to rely on their accumulated capital to survive this period. However, the owner B gives a surprising answer to that issue stating what follows: 
'(...) we did not have a problem with clients at that time. We actually had clients all the time, including this period. I think it is the matter of the way we advertised ourselves. Clients spread the information about our company and they advertised us to their friends (...). I also consciously checked clients before signing the agreement and starting to work (...)'. It is surprising, while both of these companies at the time of the financial crisis were well-recognized businesses, serving large and demanding clients.

As can be seen, both in case of a company A and B the main cause of organizational problems were clients (large companies) and their lack of willingness to pay for services or products.

Owners of two companies declared they reacted to disruptive events in slightly diverse manner. Although there are numerous similarities in actions and decisions, there are also some clearly distinguishing reactions. In the case of company A, owner declares that he has done everything that was possible to force clients to pay. After numerous quarrels, formal meetings, phone calls, he ended up by suing the client, however, as he states 'the legal regulations in Poland are constructed in such a way that they allow for destruction of company. How to say it? It's a pathology. In construction business it works like this: you sing a contract with a client, and there are conditions to be met. And it is very simple not to fulfill the contract, in particular, the client will not sing-in monthly report (does not accept the work you've done). There is nothing you can do about it. And courts favor institutions like tax office, not entrepreneurs. Before you get your money you have to spend more to continue the contract, and have to pay to tax office or other institutions'. In this way the company failed, but as manager says, in the 2011-2014 '(...) it was not a management at all (...), it was solely attempt to survive'. He tried to overcome problems by finding external institution that would help him financially, but after putting in some capital to the firm it occurred, that this business angel company was unable to provide financial services in time, and the company A slowly started to lose its reputation - with other clients and, what is more difficult - in relation to its suppliers. The company, from rapidly growing in 2005-2011, after 2011 quickly started to loosing customers and was forced to reduce the number of employees. As manager claim, nearly all of them were transferred to two other companies, so that they could continue working in the field. They went there with the company proprietary know how. In 2014 all possible machines and vehicles were sold to pay debts and in beginning of 2015 the company officially went bankrupt. However, as owner states, it was bankrupt long before 2015, and 'there was nothing I could do about it'.

From the very beginning the owner managed the company by himself, he did not use external advisors and he has not have any lawyers in the company. Also, all the important decisions were made by himself, and he feels responsible for what has happened. However, he said there would be nothing to change if he is to start his new company. He would organize it the same way. This is how he says about it "there was nothing I did wrong. I always did a business this way 
and it worked. And it was one client, one big contract, one thief that broke my company. (...) I worked with clients with a high level of trust. This is how construction works'.

On the other hand, the second owner (owner B) had exactly the same situation, in which he also had several significant clients and all of them stopped paying for services at certain period of time. Although, his approach was different - he focused on personal contacts and slowly convinced clients to pay sometimes only part, and sometimes total amount that was due. During financial problems the owner of second company focused on patience; conscious choices of clients and checking their status. This is what he actually says about his relationships with clients: '(...) every time there was a question or inquiry sent to us regarding starting an investment and building some houses I carefully checked my clients. I searched in the internet, I asked friends, I phoned other companies. All in secret, obviously. If I had any doubts, I refused to serve such customers (...)'.

Interesting observation arises from comparison of management approach declared by both owners. Both of them stated explicitly, they were the persons responsible for management. The second owner formulates it this way '(...) I always felt management is my and my wife's duty. It is not an interest of my employees. It is my obligation. I manage, they work (...) so, I am also responsible for them and for their families (...)'. The owner of the company A state it differently '(...) I was responsible for the whole company. There was a production manager responsible for hiring and firing employees, but I was responsible for all contracts and clients. It was my duty to make the company work. And I never had any advisors in my field. All the important, strategic decisions were made by me, and me solely (...)'.

It may be argued that this reluctance to listen to customers, clients and other stakeholders differentiates both companies. While the first owner made decisions all by himself, the owner of the company B had advisors at the initial stage - several specialists from the field, from other companies, and they helped him make all the important, initial decisions.

\section{Discussion}

Presented above differences and much broader material gathered during interviews allows for in-depth comparison (table 1). We chose the extended and modified framework proposed by Kantur and Say (2015, pp. 456-472) to compare both companies. We enriched it with the attitude towards opportunities and threats, locus of organizational attention, the level of professionalization, and familiness, as important for family businesses. The comparison presented in table 1 contains a list of propositions that should be tested empirically to better understand actions and behaviors of companies in the face of crisis. In particular, research attention should be focused on aspects that differentiate successful and unsuccessful company. We decided not to formulate 
propositions explicitly, while there would be lots of them. Instead, we present a comparison that is a good starting point for creating concrete research propositions (hypotheses).

\section{Conclusion}

The comparison presented above shows differences and similarities, and there is no simple explanation why the first company failed and the second survived. The approach to management, taking care of the company, treating employees are very similar. However, what strikingly astonishes is the attitude towards clients and the strategy in the search of the opportunities (as well as perception of threats). During critical situation more attention should be placed on safeguarding mechanisms and double-checking reliability of clients. Also, although low level of professionalization of management does not diminish the chances to survive, consultations with experienced institutions may help in making right decisions.

\section{References}

Amann, B., \& Jaussaud, J. (2011). Family and non-family business resilience in an economic downturn. Asia Pacific Business Review, 18(2). doi:10.1080/1 3602381.2010 .537057$.

Angrosino, M. (2007). Doing ethnographic and observational research. London: Sage. doi:10.4135/9781849208932.

Bhamra, R., Dani, S., \& Burnard, K. (2011). Resilience: The concept, a literature review and future directions. International Journal of Production Research, 49(18). doi:10.1080/00207543.2011.563826.

Boin, A. \& van Eeten, M.J.G. (2013). The resilient organization. A critical appraisal. Public Management Review, 15(3) doi:10.1080/14719037.2013.7698 56.

Butts, C.T., Acton, R.M., \& Marcum, C. (2012). Interorganizational collaboration in the Hurricane Katrina response. Journal of Social Structure, 13.

Carlock, R.S., \& Ward, J.L. (2001). Strategic planning for the family business. New York: Palgrave.

Charmaz, K. (2011). Grounded theory methods in social justice research. In N.K. Denzin, Y.S. Lincoln (Eds.), The Sage handbook of qualitative research. Los Angeles: Sage. doi:10.4135/9781446212165.n27.

Danes, S.M., Lee, J., Amarapurkar, S., Stafford, K., Haynes, G., \& Brewton, K.E. (2009). Determinants of family business resilience after a natural disaster by gender of business owner. Journal of Developmental Entrepreneurship, 14(04). doi:10.1142/s1084946709001351.

Eisenhardt, K.M. (1989). Building theories from case study research. Academy of Management Review, 14(4). doi:10.5465/amr.1989.4308385. 
Hamel, G. \& Valikangas, L. (2003). The quest for resilience. Harvard Business Review, September.

Harris, D., Martinez, J.L., \& Ward, J.L. (1994). Is strategy different for the family owned businesses? Family Business Review, 7(2). doi:10.1111/j.1741-6248.1994.00159.x.

Holling, C.S. (1973). Resilience and stability of ecological systems. Annual Review of Ecology and Systematics, 4. doi:10.1146/annurev.es.04.110173.000245.

Hollnagel, E., Woods, D.D., \& Leveson, N. (2006). Resilience engineering: Concepts and precepts. Aldershot: Ashgate.

Instytut Biznesu Rodzinnego. (2016). Firma rodzinna to marka. Retrieved 27.02.2018 from http://www.ibrpolska.pl.

Jeżak, J. (Ed.). (2015). Przedsiębiorstwa rodzinne w Polsce. Znaczenie ekonomiczne oraz strategiczne problemy rozwoju. Łódź: Wydawnictwo Uniwersytetu Eódzkiego.

Kachaner, N., Stalk, G., \& Bloch, A. (2012). What you can learn from family business. Harvard Business Review, November.

Kantur, D., \& Say, A.I. (2015). Measuring organizational resilience: A scale development. Journal of Business Economics \& Finance, 4(3). doi:10.17261/ Pressacademia.2015313066.

Kets de Vries, M.F.R., Carlock, R.S., \& Florent-Treacy, E. (2007). Family business on the couch: A psychological perspective. London: Wiley.

Lumpkin, G.T. \& Dess, G.G. (2001). Linking two dimensions of entrepreneurial orientation to firm performance: The moderating role of environment and industry life cycle. Journal of Business Venturing, 16(5). doi:10.1016/ s0883-9026(00)00048-3.

Majda, A. (2015). Succession strategy in polish family businesses - a comparative analysis. Research Papers of Wroctaw University of Economics, 402. doi:10.15611/pn.2015.402.19.

Powley, E.H. (2009). Reclaiming resilience and safety: Resilience activation in the critical period of crisis. Human Relations, 62(9). doi:10.1177/0018726709334881.

Sheffi, Y. (2005). Building a resilient supply chain. Harvard Business Review. Supply Chain Strategy, 1(5).

Shin, J., Taylor, M.S., \& Seo, M.G. (2012). Resources for change: The relationships of organizational inducements and psychological resilience to employees' attitudes and behaviors toward organizational change. Academy of Management Journal, 55(3). doi:10.5465/amj.2010.0325.

Somers, S. (2009). Measuring resilience potential: An adaptive strategy for organizational crisis planning. Journal of Contingencies and Crisis Management, 17(1). doi:10.1111/j.1468-5973.2009.00558.x.

Turner, N. \& Kutsch, E. (2016). Understanding resilience in organizational operations - an ambidexterity perspective. Academy of Management Proceedings, 1. doi:10.5465/ambpp.2016.11836abstract. 
van der Vegt, G.S., Essens, P., Wahlstrom, M., \& George, G. (2015). From the Editors: Managing risk and resilience. Academy of Management Journal, 58(4). doi:10.5465/amj.2015.4004.

Williams, T.A., Gruber, D.A., Sutcliffe, K.M., Shepherd, D.A., \& Zhao, E.Y. (2016). Organizational response to adversity: Fusing crisis management and resilience research streams. Academy of Management Annals, 12(1). doi:10.5465/annals.2015.0134.

\section{Acknowledgements}

Author contributions: authors have given an approval to the final version of the article. Authors contributed to this work as follows: T.I. and G.G. developed the concept and designed the study, T.I. collected the data, T.I. analysed and interpreted the data, G.G. prepared draft of article, T.I. revised the article critically for important intellectual content.

Funding: this research was fully funded by the University of Economics in Katowice, Faculty of Economics, Department of Entrepreneurship and Innovation Management statutory sources.

Note: the results of this study were presented at 9th International Conference on Applied Economics Contemporary Issues in Economy (June 22-23, Torun, Poland). 


\section{Appendix}

Table 1 .

\section{Comparison of companies' reactions to destructive events}

\begin{tabular}{|c|c|c|}
\hline Specification & Company A & Company B \\
\hline $\begin{array}{l}\text { attitude } \\
\text { to opportunities }\end{array}$ & active seeking and creating of opportunities & active seeking and creating of opportunities \\
\hline attitude to threats & $\begin{array}{l}\text { faith in other stakeholders, lack of safe- } \\
\text { guarding mechanisms for unreliable clients }\end{array}$ & $\begin{array}{l}\text { continuous examination of potential clients } \\
\text { for threats }\end{array}$ \\
\hline $\begin{array}{l}\text { locus of organizational } \\
\text { attention }\end{array}$ & attention focused on client search & $\begin{array}{l}\text { attention focused on client search and cli- } \\
\text { ent verification }\end{array}$ \\
\hline $\begin{array}{l}\text { level } \\
\text { of professionalization }\end{array}$ & $\begin{array}{c}\text { low to medium (strategic management } \\
\text { issues carried by owner, operational man- } \\
\text { agement delegated) }\end{array}$ & $\begin{array}{l}\text { low (most of strategic and operational } \\
\text { decisions made by the owner) }\end{array}$ \\
\hline familiness & $\begin{array}{l}\text { high level of familiness, wife working } \\
\text { in a company, company prepared for } \\
\text { owners' children }\end{array}$ & $\begin{array}{l}\text { high level of familiness, wife working } \\
\text { in a company, company prepared for } \\
\text { owners' children }\end{array}$ \\
\hline $\begin{array}{l}\text { preserving position } \\
\text { activities }\end{array}$ & $\begin{array}{l}\text { trying to minimize consequences for } \\
\text { the staff by finding them new jobs; trans- } \\
\text { ferring capital to other companies; search- } \\
\text { ing for help in external business angel; } \\
\text { legal process with clients; 'escaping' with } \\
\text { the capital; searching for help in banks } \\
\text { (with no luck) }\end{array}$ & $\begin{array}{l}\text { continuous monitoring and demands for } \\
\text { payments, focus on searching for new } \\
\text { clients, investing own money, searching for } \\
\text { help in other companies, among friends, } \\
\text { using 'capital slack' that was at the disposal } \\
\text { of the company, bank credits }\end{array}$ \\
\hline diversification & concentration on current business & $\begin{array}{l}\text { searching for other possibilities (opening } \\
\text { tennis and fitness club) }\end{array}$ \\
\hline rapidity & quick, immediate actions & quick, immediate actions \\
\hline $\begin{array}{l}\text { alternatives to benefit } \\
\text { from }\end{array}$ & $\begin{array}{l}\text { initially smaller clients and slowly starting } \\
\text { to serve larger companies (b2b business), } \\
\text { usually one or two at a certain moment }\end{array}$ & $\begin{array}{l}\text { initially large clients, and slowly evolving } \\
\text { and concentrating on smaller clients } \\
\text { to safeguard the processes and wellbeing } \\
\text { of a company }\end{array}$ \\
\hline agility & $\begin{array}{l}\text { large investments in relation specific assets, } \\
\text { low agility }\end{array}$ & $\begin{array}{l}\text { high agility and diversified knowledge, low } \\
\text { investments in specific assets }\end{array}$ \\
\hline $\begin{array}{l}\text { employee } \\
\text { commitment }\end{array}$ & high commitment and loyalty of a staff & high commitment and loyalty of a staff \\
\hline acting as a whole & $\begin{array}{c}\text { changes in the company fully under- } \\
\text { stood, employees transferred to two other } \\
\text { companies }\end{array}$ & $\begin{array}{c}\text { changes in the company fully understood, } \\
\text { the staff well integrated, decisions made } \\
\text { only by the owner }\end{array}$ \\
\hline $\begin{array}{l}\text { resistance } \\
\text { and continuance }\end{array}$ & $\begin{array}{l}\text { resignation, feeling cheated and robbed; } \\
\text { the attempt to 'save' the company during } \\
\text { the crisis, and later — attempts to guaran- } \\
\text { tee future for employees }\end{array}$ & $\begin{array}{l}\text { proactive posture, motivated to action, } \\
\text { trying to understand and explain behaviors } \\
\text { of customers; patience and waiting for } \\
\text { a right moment to demand for payment }\end{array}$ \\
\hline
\end{tabular}

Source: Own preparation. 
